\title{
Preprints of Proceedings
}

International Specialized Conference on Design and Operation of

\section{SMALL WASTEWATER TREATMENT PLANTS}

\author{
Trondheim, Norway \\ 26 - 28 June 1989 \\ Edited by \\ Hallvard Ødegaard
}

\section{Scientific Programme Committee}

Professor H. Ødegaard, Norway (Chairman)

Professor P. Balmer, Sweden

Professor M. Vittasaari, Finland

Mr. J. La Cour Jansen, Denmark

Dipl.Ing. K. Bucksteeg, Federal Republic of Germany

Dr. M. Boller, Switzerland

Prof. K.K. Chin, Singapore

Dr. D.D.C. Cantwell, England

Mr. D. Ballay, France

Dr. T. Matsuo, Japan

Dr. E. Smith, USA

Siv.ing. B. Paulsrud, Norway

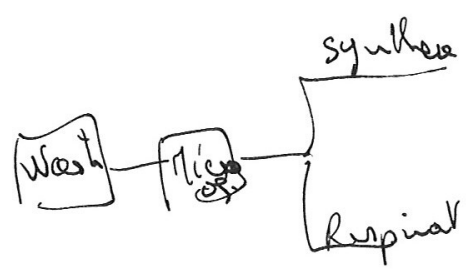




\section{CQELY.29108}

QUALITATIVE AND QUANTITATIVE CHARACTERIZATION

OF WASTE WATER FOR SMALL COMMUNITIES

\section{R.PUJOL and A.LIENARD}

CEMAGREF - "Division Qualité des Eaux"

3, Qua1 Chauveau - 69336 Lyon Cedex 09 - FRANCE

\section{ABSTRACT}

An understanding of the waste water nature, from both the qualitative and quantitative points of view, is a fundamental factor in the selection of treatment techniques and their subsequent operation. This is even more so in the case of small communities whose discharges are more subject to variation. An analysis of French data in this field provides values for small communities in rural areas (the majority). So far as other communities are concerned there are three examples which particularly illustrate the effects of the different factors (way of life...) on specific loads.

\section{KEYWORDS}

Waste water - small communities - flows - concentrations - specific loads.

\section{INTRODUCTION}

The protection of water supplies involves treatment plants both in heavily organized areas and in those with a low population density where the nature of the receiving environment is often fragile. The financial investment required is all the greater when the community is small.

In order to carefully select the treatment process according to economical and technical criteria, it is first of all necessary to have a full knowledge of the waste water to be treated. In the case of small communities, qualitative and quantitative variations in waste water are in relation to the avallability of water supplies, the way of life (time spent at home), the level of hygiene and comfort (extent of sanitary and household equipment).

The term "small communities" covers a very wide diversity of situations. Here, we are concerned principally with data relating to small rural communities which constitute a predominant group. The main characteristics of such waters will be analysed (flows, concentrations, loads), as well as their development over a period of time, based on the study of a typical community.

For comparison, data relating to three specific small communities will be described : an hospital, a children's centre, a mountain refuge.

\section{CHARACTERISTIC PARAMETERS OF WASTE WATER}

Pollutants in water are identified by techniques involving an analysis of the different components. The most frequently used parameters are :

- Suspended Solids (SS) and its organic fraction, Volatile Suspended Solids (Vss) which characterize the particular type of pollution, 
the Chemical Oxygen Demand (COD) and the Biochemical Oxygen Demand in five days (BOD), these parameters quantify the organic content of the waste water,

- forms of nitrogen $(N)$ and phosphorus (P), fertilizing elements whose discharges are, under certain conditions, likely to accelerate the eutrophic process,

- the $\mathrm{pH}$ and the conductivity, which give a good indication of the water ionocity.

In special cases, temperature must be taken into account (mountainous areas); microbiological analysis (faecal contamination germ tests) are necessary if there is a health risk (bathing
areas, shellfish breeding...).

The volume of water discharged must also be determined : the dimensioning of installations depends in principle on the daily quantities to be treated, peak flows having a major role in the case of certain tanks (pretreatment, clarifiers). Much information can be obtained by analysing hourly flow curves, for example the night water volume gives an indication on clear water infiltration into the sewerage systems.

Concentrations and flows can be used to calculate the pollution load, a well known notion in waste water treatment. The pollution load is equal to the product of the flow volume by the concentration of a representative sample of the water quality discharged during the same
time.

Current practice is to divide the load values by the number of inhabitants connected to the network; these specific values are known as "persons equivalent" (p.e.).

\section{Origin of waste water}

The characteristics of domestic waste water are linked to their origin. There are :

- sewage water from toilets. This represents approximately 301 per day and per user. It contains essentially organic matter.

- domestic water from kitchens, bathrooms,... Their daily volume can vary considerably depending on the extent of the equipment and the hygienic habits (showers, baths,...). Generally speaking, consumption of household water is high in an urban area ( 100 to 3001 per day per user), but is smaller in a rural environment (50 to 1001 per day per user). These waters contain principally organic matter as well as household products (detergents,
phosphates...).

\section{WASTE WATER IN SMALI RURAL COMMUNITIES}

For most of the time, such water is predominantly domestic, even if, sometimes, a particular local activity or small industries generate waste water collected by the sewerage system
(butchers, restaurants...).

Data relating to waste water from rural communities has been collected during surveys of treatment plants involving the determination of the pollutants flows into the installations. The results are taken from measurements made in dry weather on good separated sewerage systems. The mean daily samples taken from the sewerage system are made up in proportion to the measured hourly flows. The concentrations of these samples have been calculated in accordance with standard French analytic procedures.

The mean results obtained from some thirty rural waste water treatment plants (population ( 5000 inhabitants) are given in table 1 .

Table 1 - Main characteristics of the waste water in rural communities

$\mathrm{COD}=700 \mathrm{mg} / 1 \pm 100$
$\mathrm{BOD}=300 \mathrm{mg} / 1 \pm 65$
$\mathrm{SS}=250 \mathrm{mg} / 1 \pm 30$
$\mathrm{~N}=80 \mathrm{mg} / 1 \pm 20\left(60 \mathrm{mg} \mathrm{N}-\mathrm{NH}_{4}^{+}\right)$
$\mathrm{P}=35 \mathrm{mg} / 1$


The COD and BOD concentrations confirm the organic nature of the waste water. The COD/BOD ratio, which is slightly greater than 2, indicates the biodegradable nature of such water. The $\mathrm{N}$ and $\mathrm{P}$ concentrations permit any biological process (BOD/N/P ratio $=100 / 26.6 / 11.6$ ).

To complement these characteristic values it should be noted that the mean temperature of water collected approaches $15^{\circ} \mathrm{C}$ (extremes $10^{\circ} \mathrm{C}-18^{\circ} \mathrm{C}$ ). In cold mountain areas the minimum measured was $4^{\circ} \mathrm{C}$, but the sewerage system collected large quantities of waters from melting snow (this data has not been taken into account when drawing up table 1). Concentrations of greases (substances which can be extracted using chloroform) are less than $100 \mathrm{mg} / 1$. The $\mathrm{pH}$ is normally alkaline, between 7.5 and 8. Exceptionally, in the case of long sewerage systems or when the slope is slow, a pH less than 7 indicates the septicity of such water (prolonged stay in the sewer). The waste water contains some $10^{9}$ of total coliforms per litre.

When preparing projects for waste water plants, load measurements are generally not possible, the pollution flow calculation is based on specific values related to a user connected to the sewerage system (the person-equivalent already referred to).

On the basis of results shown in table 1, these calculations give the daily discharge of one person-equivalent (table 2):

Table 2 - Guide values for one person-equivalent (p.e) in rural area

\begin{tabular}{|llrlll|}
\hline Volume & $=$ & $1501 \pm 50$ & \\
COD & $=$ & 75 & to $80 \mathrm{~g}$ \\
BOD & $=$ & 30 & - & $35 \mathrm{~g}$ \\
SS & $=$ & 25 & $-30 \mathrm{~g}$ \\
N & $=$ & 8 & $9 \mathrm{~g}$ \\
P & $=$ & $3,5-4 \mathrm{~g}$ \\
\hline
\end{tabular}

These figures are lower than the absolute values generally used for an urban area (eg. BOD $=50$ to $60 \mathrm{~g}$ per person-equivalent).

\section{Analysis of variation factors}

The preceding data is useful as a guide, but it must be weighted to take account of local factors.

The first variation factor as to concentrations and flows is the presence of clear water in the sewerage system. The greater the quantity of infiltrated water the greater the degree of dilution, concentrations are reduced and the hydraulic load increases. Apart from the fact that more treatment will be required, the admission of large quantities of clear water into the sewerage system may have other unfortunate consequences, such as reduced efficiency of the settling tanks or, in the most critical cases, the impossibility of initiating a biological process (absence of floculation...); this was the case of one plant where the volume of water by person-equivalent exceeded $1 \mathrm{~m}^{3}$.

The second variation factor relates to specific activities (small workshops, semi-industrial activities) which may modify to a greater or lesser extent the concentrations of the water to be treated. It is not unusual to find in a village some establishment of this type whose discharges may, in due course, prejudice the satisfactory functioning of the treatment plant, unless special constructive measures are taken.

Finally, criteria such as the length and type of the sewerage system (separate, combined), the collection of water from numerous septic tanks, may have an incidence on the nature of the water requiring treatment.

\section{ANALYSIS OF VARIATIONS FOR A PLANT IN A RURAL ZONE}

Do the concentrations and flows recorded at the inlet plant vary?

The reply to this question, based on a survey in a rural community of 2000 person-equivalents, is not clear. 
Measurements were made over a period of one week; the main hourly values were analysed in detail over a 24 hours cycle (from Monday at $3 \mathrm{pm}$ to Tuesday at $3 \mathrm{pm}$ ).

The daily pollution load was stable between 14 and $17 \mathrm{~kg}$ BOD/day over a period of one week. The installation underload (dimensioned on the basis of $100 \mathrm{~kg} \mathrm{BOD} /$ day) was important. The has plant has been in operation for three on the other hand, on the basis of one day, hourly variations in bath flow and concentration were considerable (Figure 1).

Fig 1: SIMULTANEOUS VARIATIONS OF

\section{COD, BOD AND FLOW DURING 24 HOURS}

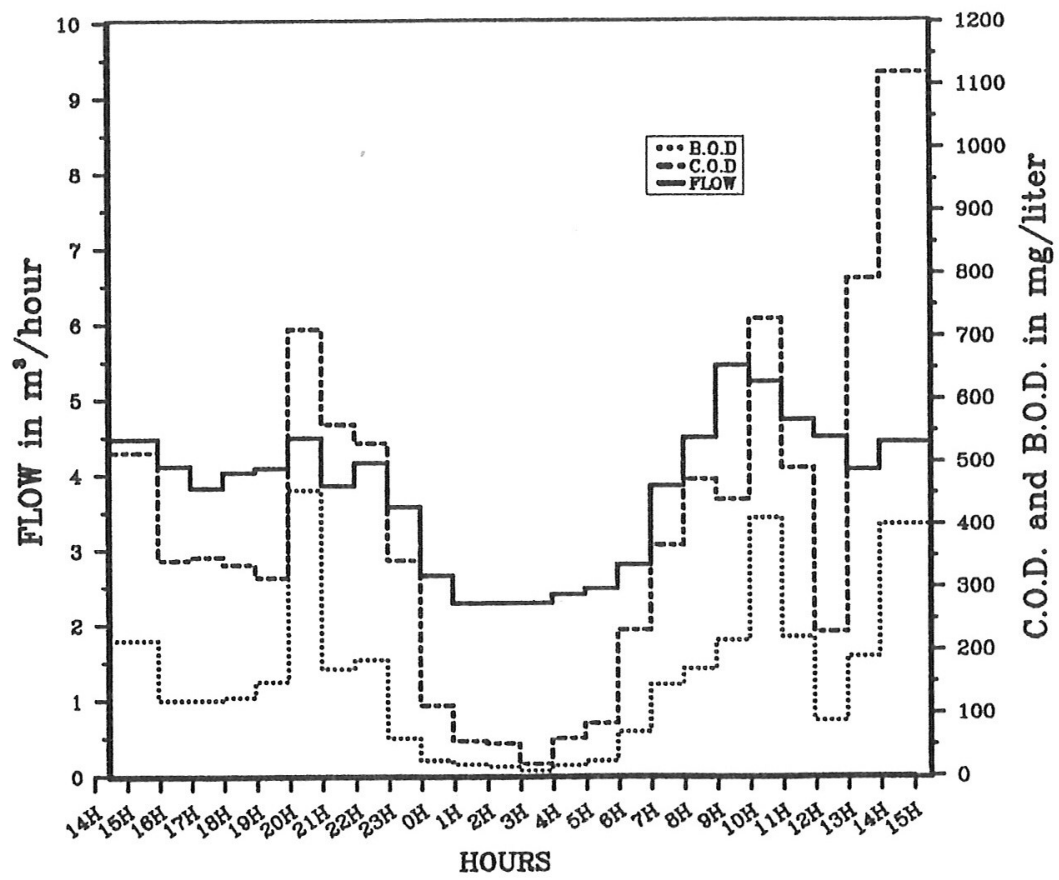

An analysis of the graphs shows that in the first place the equivalence of the pollution peaks and the town's activities. These peaks are particularly marked in the morning, at the beginning of the afternoon and in the evening. On the other hand, at night the concentration of waste water is very low (COD $<50 \mathrm{mg} / 1$ between $3 \mathrm{am}$ and $4 \mathrm{am}$ ). The highest flows correspond fairly closely to the peaks of concentration, the maximum being recorded between 9 am and $11 \mathrm{am}$. Flow values at night represent approximately $2 \mathrm{~m}^{3} / \mathrm{h}$ and consist of clear water infiltrated into sewerage system ie. approximately $50 \%$ of the total flow.

These measurements were made in dry weather and the system can be considered as draining. Pollution loads varied considerably $(0.05 \mathrm{~kg}$ COD between $3 \mathrm{am}$ and 4 am; $5.96 \mathrm{~kg}$ COD between $2 \mathrm{pm}$ and $3 \mathrm{pm}$ ). Such fluctuations are normal for smal1 communities. The traditionnally used, (in general activated sludge with extended aeration) can handle them without difficulty. Fluctuations in flow undoubtedly disturb the operation of small plants to a greater extent, in effect losses of sludge often occur in the afternoon (after the morning and midday peaks) in activated sludge plants, when the settleability is poor. The main results collected during the detailed survey over a 24 hours cycle are given in table 3 . 
$\underline{\text { Table } 3}$ - Main results of the survey

\begin{tabular}{|l|r|r|r|}
\hline Hour & Flow & BOD & COD \\
\hline Mean & $3,8 \mathrm{~m}^{3} / \mathrm{h}$ & $170 \mathrm{mg} / 1$ & $436 \mathrm{mg} / 1$ \\
\hline Minimum & $2,2 \mathrm{~m}^{3} / \mathrm{h}$ & $10 \mathrm{mg} / 1$ & $20 \mathrm{mg} / 1$ \\
\hline Maximum & $5,5 \mathrm{~m}^{3} / \mathrm{h}$ & $450 \mathrm{mg} / 1$ & $1.100 \mathrm{mg} / 1$ \\
\hline \multicolumn{3}{|c|}{ Ratio COD $/$ BOD $=2,56$} \\
\hline
\end{tabular}

\begin{tabular}{|lc|}
\hline & $\begin{array}{l}\text { Specific loads per } \\
\text { person-equivalent }\end{array}$ \\
\hline Flow & $182 \mathrm{I}$ \\
\hline COD & $78 \mathrm{~g}$ \\
\hline BOD & $30 \mathrm{~g}$ \\
\hline
\end{tabular}

The comparison of these results with the main characteristics of tables 1 and 2 shows:

- concentrations are lower because dilution,

- specific loads are fully in conformity with these of rural communities.

In the case of this plant, flows are at present at $30 \%$ of the rated value, the organic load does not reach $15 \%$; this situation is representative of a wide sample of French waste water treatment plants.

\section{CHARACTERISTICS OF WASTE WATERS IN FEW SPECIFIC SMALL COMMUNITIES}

Although villages account for a large part of rural communities there are also many isolated establishments open to the public, small housing estates...

In this case there is no need to draw up an exhaustive list of these different establishments, a few examples will suffice to demonstrate the analogies or differences in their waste water as compared with the general case of the previously studied rural communities.

\section{An isolated hospital}

This hospital receives approximately 250 to 300 patients requiring only limited treatment, the majority being convalescent. Together with the personnel total numbers do not reach 500 persons.

Waste water is collected and discharged into an activated sludge plant 300 metres from the hospital.

This plant is monitored by the SATESE of Loire Atlantique (service of technical aid to wastewater treatment plant managers) which make regular measurements at the plant, the main results described are based on various measurements made by this service.

The volume of waste water is relatively stable (40 to $50 \mathrm{~m}^{3} /$ day) with occasional peaks of $70 \mathrm{~m}^{3} /$ day which correspond to the main washing days in the establishment.

Concentrations of water occasionnally reach $1600 \mathrm{mg}$ COD/1, sufficient quantities of nitrogen and phosphorus have been observed in the influents. The mean daily load expressed in BOD is $16 \mathrm{~kg} /$ day for 410 persons.

A comparison with the reference rural community confirms the domestic character of the inffluents $(C O D / B O D=2.5)$. The only differences concern the concentration of the water which is higher (absence of any infiltration of clear the specific load, which is relatively high (39 g BOD per person-equivalent). Another difference relates to the temperature of the waste water which can reach $30^{\circ} \mathrm{C}$ (washing with
hot water).

\section{A children's centre}

This centre receives some sixty children and pre-adoslescents, the activity of this establishment follows the school periods.

The waste water is treated by two macrophyte beds treatment plants. 
The most recent installation (which only receives part of the centre's waste water) was the subject of detailed analyses, particularly as to the characterization of the water to be presterage system supplying this plant is short, in addition there is no pretreatment (coarse screening, degreasing) at the inlet and the raw inffluent is received
by the first stage of reed beds.

Given the hetorogeneity of the inffluent, a special sampling procedure had to be used. The representative samples were collected by separating the grid, crushed, homogenized and finer particles in suspension and the liquid containing the the usual sampling devices with a peristaltic pump.

The mean results for eight - 24 - hours measurements programmes spread over a period of 5 years are shown in table 4 .

Table 4 - Measurements of pollution loads in a children's centre (mean values).

\begin{tabular}{|c|c|c|c|c|c|c|c|}
\hline & $\begin{array}{c}\text { Flow } \\
\text { in } 1 / \text { day }\end{array}$ & COD & BOD & $\begin{array}{c}\text { SS } \\
\text { in } g / c\end{array}$ & NK & PT & $\begin{array}{l}\text { Anionic } \\
\text { detergent }\end{array}$ \\
\hline Mean & 6.626 & 5.177 & 2.151 & 1.867 & 440 & 113 & 65 \\
\hline $\begin{array}{l}\text { Standard- } \\
\text { deviation }\end{array}$ & 1.539 & 1.287 & 814 & 667 & 86 & 42 & 30 \\
\hline $\begin{array}{l}\text { Coefficient of } \\
\text { variation in } \%\end{array}$ & 23,2 & 24,9 & 37,8 & 35,7 & 19,5 & 37,2 & 46,2 \\
\hline
\end{tabular}
These figures relate to day of full activity and were obtained during weekdays out of holiday
periods.

The variations recorded were however relatively important and were due to

- the internal reorganization of the activities (grouping together of all the centre's apens,

unit of aprable daily fluctuations (washing days, cleaning of floors), normal for a unit of this size with an organized structure,

On the other hand, solid matter retained on the $1 \mathrm{~cm}$ grid screen was always within a bracket representing respectively :

-0.2 to $0.4 \%$ of the volume of water screened,

- 5 to $7 \%$ of the overall coD load, The resultant pollution load coulds be considered as equivalent to 62 persons, corresponding
to:

- permanent activity of 24 adolescents and 8 adults,

- preparation of meals and the washing of linen for 60 children, equivalent to that for 30 persons full time, On the basis of mean calculations, the specific ratios per inhabitant-equivalent can be
calculated:

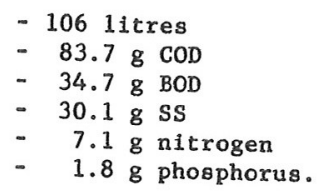

It will be noticed that these do not differ very much from those shown in table 2 but are subject to considerable variations in time. 


\section{A high mountain refuge}

Located at $2600 \mathrm{~m}$ in the French Alps, 2 hours walk from a town, the refuge has 200 beds and limited sanitary facilities ( 7 toilets, 11 washbasins, 4 water points).

The restaurant can seat approximately one hundred persons per service.

Detailed investigations were made over a period of 5 days in summer (maximum occupancy and water available).

The occupancy results for the refuge are summarized in table 5 .

Table 5 - Occupancy of the mountain refuge

\begin{tabular}{|c|c|c|c|}
\hline Day & $\begin{array}{c}\text { Number of } \\
\text { visitors }(8 \text { a.m-6 p.m })\end{array}$ & $\begin{array}{c}\text { Nights }= \\
\text { beds occuped }\end{array}$ & Weather \\
\hline 1 & 1.700 & 191 & Sunny \\
\hline 2 & 450 & 98 & Cloudy \\
\hline 3 & 650 & 160 & Variable \\
\hline 4 & 230 & 78 & Rainy \\
\hline 5 & 1.100 & 190 & Sunny \\
\hline Mean & 826 & 143,4 & \\
\hline
\end{tabular}

The occupancy of the refuge is closely linked to weather conditions. The occupancy rate gave an average of $71 \%$ of the refuge's total capacity.

The maximum number of meals served was 150 (first day of the survey). The flow of waste water had the characteristics indicated in table 6 .

Table 6 - Characteristics of waste water from the mountain refuge

\begin{tabular}{|c|c|c|c|c|c|c|}
\hline \multirow{2}{*}{ day } & Flow & \multicolumn{5}{|c|}{ Loads in $\mathrm{kg} / \mathrm{day}$} \\
\hline & $1 /$ day & COD & BOD & ss & $\mathrm{N}$ & $P$ \\
\hline 1 & 8.395 & 9,57 & 3,69 & 2,68 & 2,28 & 0,2 \\
\hline 2 & 7.556 & 7,07 & 2,35 & 2,21 & 1,23 & 0,1 \\
\hline 3 & 6.948 & 9,14 & 2,78 & 2,55 & 1,61 & 0,1 \\
\hline 4 & 6.041 & 6,80 & 2,11 & 2,04 & 1,24 & 0,1 \\
\hline 5 & 8.743 & 7,87 & 3,58 & 1,60 & 1,89 & 0,1 \\
\hline Mean & 7.538 & 8,09 & 2,90 & 2,21 & 1,65 & 0,1 \\
\hline
\end{tabular}

Accumulated flows for a day do not give an idea of hourly variations (mimimum flow nearly zero at night and a maximum flow of $1 \mathrm{~m}^{3} /$ hour). The peak coefficient is about 3 . These values are explained by the short length of the sewer.

Samples taken after coarse screening were very concentrated (mean $\operatorname{COD}=1.073 \mathrm{mg} / 1$ ). Their domestic characteristics are obvious in spite of a COD/BOD ratio of nearly 3 , explained by the high proportion of cellulose in the water (torn up paper).

Flow and concentration peaks were principally in the evening ( $7 \mathrm{pm}$ ) and in the morning ( $7 \mathrm{am}$ ). 
As an indication, the volume of waste recovered after coarse screening was $161 /$ day, ie. approximately $500 \mathrm{~g}$ COD/day, that is to say less than $10 \%$ of the total pollution load.

An analysis of all the data (including residues of coarse screening), weighted by safety coefficients for the flows, gives a maximum specific flow reference of $25 \mathrm{~g}$ BOD per "night equivalent" and a corresponding flow of $451 /$ day in dry weather. This value can reach $801 /$ day with rain water.

These results, which are not very high, are explained by the small quantity of household and sanitary equipment, the limited availability of water and the very special conditions of life in this type of establishment.

\section{CONCLUSION}

Three main points emerge from this qualitative and quantitative analysis of the waste water of small communities :

- the volumes and concentrations of discharges depend on the way of life of the users, the level of equipment of the dwellings, the hygiene habits.

- the scale of variation in the flow of pollutants varies inversely with the size of the community.

- the length and condition of the sewerage system (infiltration of clear water) have a direct effect on the volume of water collected and the water concentration.

Small rural communities are a very important group for which the characteristics of waste water are known: the mean ratios correspond to $1501 /$ day and 328 BOD/day per person-equivalent. Depending on the condition of the sewerage system, the volume of water will be greater if it is very draining, but the volume will rarely fall below $801 /$ day even for a short and really separated system. The mean figure of $32 \mathrm{~g}$ BOD/day is less than the comonly accepted values for urban areas, in future the increase in this ratio should be moderate.

In the absence of specific measurements it is difficult to give precise data for other communities. The cases studied demonstrate the importance of some factors affecting the pollution load discharged (rhythm of activity, internal organization,...).

\section{BIBLIOGRAPHY}

- C.T.G.R.B.F. (1973).- Caractéristiques des effluents des communes rurales - Note Technique $n^{\circ} 5-8 p$.

- CEMAgrer IYON (1986).- Rapport interne L 63 - Etude de la station de Saint-Bohaire - 16 p.

- CEMAGREF LYON (1987).- Rapport interne I 69 - Assainissement du refuge Félix Faure - Col de la Vanoise - Pralognan (Savole) - 28 p.

- Ministère de 1'Agriculture France (1986).- Les stations d'épuration adaptées aux petites collectivités - Document FNDAE $\mathrm{n}^{\circ} 5-60 \mathrm{p}$. 